\title{
The Effects of Resin Tapping on the Radial Growth of Masson Pine Trees in South China-A Case Study
}

\author{
Roger Williams*, Callie Nauman and Jiawei Zhu \\ School of Environment and Natural Resources, The Ohio State University, USA
}

Submission: June 21, 2017; Published: July 13, 2017

"Corresponding author: Roger Williams, School of Environment and Natural Resources, 210 Kottman Hall, 2021 Coffey Road, The Ohio State University, Columbus, OH 43210, USA, Tel: +01-614-292-2265; Fax: +01-614-292-7432; Email: williams.1577@osu.edu

\begin{abstract}
Five Masson pine (Pinus massoniana Lamb.) plantations near Liuzhou, Guangxi in south China ranging in age from 14-18 years were selected for this study. Two plantations were tapped for resin production and three plantations had not been tapped. Eight sample trees were selected from each of three sample plots randomly established in each plantation. Tree cores were extracted at $1.3 \mathrm{~m}$ on each sample tree for the purpose of measuring tree ring width to establish radial growth. Tree cores were sanded with fine grain sandpaper and measured to the nearest $0.5 \mathrm{~mm}$ with the aid of a 10x magnification scope. Some cores had to be eliminated from the sample due to poor quality, and ultimately 24 cores from tapped trees and 24 cores from untapped trees were used for analysis. The mean radial growth of tapped trees (4.4712mm) and untapped trees (4.3537) were found to be not significantly different $(\mathrm{p}=0.05)$. Models were developed to display the cumulative radial growth of trees, and the $95 \%$ confidence bounds about the model coefficients suggest there is no significant difference in the cumulative radial growth of tapped and untapped trees. While our results would suggest that there is no impact of tapping trees for resin on diameter radial growth, this might be misleading. We sampled only at $1.3 \mathrm{~m}$ and it is possible that had we sampled at $3.0 \mathrm{~m}$ we might have recorded a negative effect. The "non-effect" we recorded at $1.3 \mathrm{~m}$ may actually have been a positive effect. There could have been an increase in the radial growth due to the wood formation in the uninjured side of the tree, but was not significantly greater than that of untapped trees. Implications of this finding are discussed.
\end{abstract}

Keywords: Resin tapping; Pinus massoniana; Tree rings; Radial growth; Non wood forest products

\section{Introduction}

Masson pine (Pinus massoniana Lamb), a native species of central and southern China, has long been used as a main source of pine resin in China. Turpentine and rosin are extracts from the resin which are used to produce a variety of products such as solvents, cleaning agents for varnishes and paints, production of flavor and fragrances in the pharmaceutical and food industry, perfumes, synthetic rubber, disinfectants, coatings, printing ink resins, and waterproofing materials [1-3]. In addition to its value for resin extraction, Masson pine also has high value in regard to its use in the wood, pulp and paper industry. In fact, one study demonstrated the potential economic benefits of combined resin collection and timber production in the same stand [4]. Sometimes, however, it is more profitable for forest famers to tap trees for resin than harvesting [5].

The production of resin is a defensive response of the tree to a mechanical wound [6] where the resin flows into the wound site to form a physical and chemical barrier to prevent water loss and insect and pathogen penetration [7,8]. Accordingly growth resources, i.e., carbohydrates, of the tree move toward the wound for the purpose of resin production for defense and healing. Therefore concerns arise whether tapping trees has a negative impact on the tree growth.

Studies regarding the impact of resin tapping on tree growth have produced conflicting results. Some studies $[9,10]$ found an increase in tree radial growth of Scots pine (Pinus sylvestris L.) as a result of tapping based on their measurements of tree ring width at breast height. However, others [11] found that tapping Masson pine trees had a negative impact on radial growth. Likewise another study [12] found that tapping slash pine (Pinus elliottii Engelm.) in south China resulted in reductions in tree diameters and stocking volume.

It is apparent that there are different factors, such as differences in the autecology of a species, sampling design, and even the resin extraction method, that could produce these 
apparent conflicting results. It was the purpose of this study to determine if more light can be shed onto the subject of the effect of tapping trees for resin on tree growth. The subject species was Masson pine and the extraction method studied was the Chinese method that utilizes downward-pointing V-shaped grooves.

\section{Materials and Methods}

\section{Study area}

This study was conducted in the forests surrounding the Guangxi Eco-Engineering Technical and Vocational College near the city of Liuzhou in the Guangxi Province. The forest (approximately $\mathrm{N} 24^{\circ} 29^{\prime}$ latitude, E109 $22^{\prime}$ longitude) occupies 1,215 hectares and is comprised mostly of planted stands of Masson pine, Chinese fir (Cunninghamia lanceolata (Lamb.) Hook.) and eucalyptus hybrid (Eucalyptus urophylla $x$ E. grandis). This region lies within the southeastern edge of the subtropical monsoon climate areas of China [13]. The mean annual temperature within the region is $21.1^{\circ} \mathrm{C}$, with a maximum of $40.3^{\circ} \mathrm{C}$ in the summer and $-1.5^{\circ} \mathrm{C}$ in winter. The average annual precipitation ranges from 1200 to $1500 \mathrm{~mm}$ with average relative humidity ranging from 80 to $84 \%$. The main geomorphic types are lower mountains and hills, characterized Table 1: Plantation attributes of Masson pine plantations used in this study located near Liuzhou, Guangxi in south China.

\begin{tabular}{|c|c|c|c|c|c|c|c|}
\hline \multirow{2}{*}{ Tapping Status } & Age (Years) & $\begin{array}{c}\text { Azimuth } \\
\text { (Degrees) }\end{array}$ & Slope (\%) & Trees Per Ha & $\begin{array}{c}\text { Basal Area } \\
\text { (M2/Ha) }\end{array}$ & $\begin{array}{c}\text { Average Dbh } \\
\text { (Cm) }\end{array}$ & $\begin{array}{c}\text { Average } \\
\text { Height (M) }\end{array}$ \\
\hline \multirow{3}{*}{ Untapped } & 14 & 45 & 1 & 1593 & 33.8 & 16.1 & 14.4 \\
\cline { 2 - 8 } & 14 & 195 & 4 & 1220 & 31.9 & 18.1 & 16 \\
\cline { 2 - 8 } & 18 & 152 & 31 & 1697 & 28.4 & 14 & 13 \\
\hline \multirow{2}{*}{ Tapped } & 14 & 290 & 6 & 1033 & 26 & 17.3 & 15.8 \\
\cline { 2 - 8 } & 18 & 203 & 8 & 1533 & 28.6 & 13.7 \\
\hline
\end{tabular}

Each plot was divided into quadrants, and two trees were selected from each quadrant (for a total of 8 trees per plot) that represented the diameter distribution in the plot for tree ring measurement. One tree core was collected from each of the eight sample trees on each plot with a 3 -thread, $5.15 \mathrm{~mm}$ bore increment borer at $1.3 \mathrm{~m}$ up the bole of the tree. On tapped trees, the core was collected on the side of the tree opposite the tapping location. The cores were placed into a core holder and labeled for the purpose of measuring growth rings. Cores were sanded with a fine-grain sand paper for easier visibility of growth rings. The widths of growth rings were measured to the nearest $0.5 \mathrm{~mm}$ with an engineer's scale and the aid of a 10x magnification scope.

Because of the poor condition of some cores, it was determined that some of these cores would not provide accurate, consistent measurements of growth rings and were thus eliminated from the sample pool. Accordingly, this left 38 core samples from untapped forests and 24 samples from tapped forests. In order to acquire equal sample sizes for comparison purposes, 14 core samples were randomly selected and eliminated from the sample pool representing untapped forests. This left an equal sample size of 24 cores each for tapped and untapped forests. by rolling topography, which are dominated by moderately developed arenaceous shale red soils and strongly developed clay arenaceous shale red soils [14].

\section{Data collection}

Planted Masson pine stands, two tapped for resin and three untapped (Table 1), were sampled in May of 2013. The method used for tapping trees for resin was what has been referred to as the Chinese method, where V-shaped grooves are cut daily, deep enough to reach the secondary xylem. The first groove is cut about $1.2 \mathrm{~m}$ above the ground, and subsequent grooves are cut below it. The groove reaches roughly half way around tree's circumference and no chemical stimulants are used. Plantations were selected based on age (10-20 years) and that both tapped and untapped stands were all approximately the same age. Plantations were sampled by randomly establishing three circular 0.05 ha plots in each plantation. The diameter-atbreast-height $(\mathrm{dbh}$, nearest $0.1 \mathrm{~cm}$ ) and total tree height (nearest $1.0 \mathrm{~m}$ ) were measured and recorded with a diameter tape and clinometer, respectively, for each tree on the plot. At the plot center the slope percent and aspect were measured at the plot center using a clinometer and compass, respectively.

\section{Statistical analysis}

Analysis of Variance (ANOVA) was used to determine if differences existed in the annual tree ring width between tapped and untapped trees. Duncan's multiple range test $(p=0.05)$ was used to determine significant differences between the mean tree ring width between tapped and untapped trees. A non-linear model was developed to represent the accumulating radial growth for comparison between tapped and untapped trees. A model of the form:

$$
\mathrm{Y}=\mathrm{a}(\mathrm{x})^{\mathrm{b}}
$$

Where $Y=$ cumulative radial diameter growth $(\mathrm{mm}), \mathrm{x}=$ the number of years of growth, and a and $b$ are estimated equation coefficients, was used. The model coefficients were estimated using the Non-Linear Procedure, Gauss-Newton method in SAS software, version 9.2 [15] and the specified convergence criteria were met for the models of both tapped and untapped trees.

\section{Results and Discussion}

Analysis of variance and Duncan's multiple range tests reveal that there was no significant difference in the mean annual radial growth (tree ring width) between tapped trees and untapped 
trees (Table 2). Although no significant differences were found, tapped trees displayed slightly larger growth. This greater, although not significant, growth could be the result of wood formation occurring on the living part of the bole (opposite the tapping face) at breast height [9]. Growth cannot take place anymore on the tapping face due to the mechanical damage done to the cambium.

While our results would suggest that there is no impact of tapping trees for resin on diameter radial growth, this might be misleading. Tomusiak \& Magnuszewski [10] and van der Maaten [9] found an increased radial response to tapping at $1.3 \mathrm{~m}$ in Scots pine, but at $3.0 \mathrm{~m}$ there was no effect. We sampled only at $1.3 \mathrm{~m}$ and it is possible that had we sampled at $3.0 \mathrm{~m}$ we might have recorded a negative effect. The "non-effect" we recorded at $1.3 \mathrm{~m}$ may actually have been a positive effect. There could have been an increase in the radial growth due to the wood formation in the uninjured side of the tree, but was not significantly greater than that of untapped trees (Table 3 \& Figure 1).

Table 2: Results of analysis of variance and testing of the means ${ }^{1}$ of radial tree growth at $1.3 \mathrm{~m}$ up the tree bole of Masson pine that have been tapped for resin, compared with trees not tapped, near Liuzhou, Guangxi in south China.

\begin{tabular}{|c|c|c|c|c|c|}
\hline $\mathbf{9 5}$ Confidence Bounds & Number of Tree Core Samples & Mean Radial Growth (Mm) & RMSE & F Value & Pr > F \\
\hline Tapped & 24 & 4.4712 a & 0.7427 & 1.07 & 0.3053 \\
\hline Untapped & 24 & 4.3537 a & & & \\
\hline
\end{tabular}

${ }^{1}$ Means followed by the same letter are not significantly different at $p=0.05$, Duncan's MRT.

Table 3: The coefficients and statistics for the cumulative radial growth models ${ }^{1}$ of tapped and untapped trees of Masson pine trees near Liuzhou, Guangxi in south China.

\begin{tabular}{|c|c|c|c|c|c|c|c|c|}
\hline \multirow{3}{*}{ Tapping Status } & \multirow{2}{*}{\multicolumn{2}{|c|}{ Equation Coefficients }} & \multicolumn{6}{|c|}{ 95\% Confidence Bounds } \\
\hline & & & \multicolumn{2}{|c|}{ Coefficient a } & \multicolumn{2}{|c|}{ Coefficient b } & \multirow[b]{2}{*}{ RMSE } & \multirow[b]{2}{*}{$\mathrm{R}^{2}$} \\
\hline & $\mathrm{a}$ & $\mathrm{b}$ & Upper & Lower & Upper & Lower & & \\
\hline Tapped & 7.5842 & 0.8213 & 8.478 & 6.6904 & 0.8683 & 0.7744 & 9.2153 & 0.9661 \\
\hline Untapped & 6.9102 & 0.8259 & 7.7036 & 6.1167 & 0.8727 & 0.7791 & 9.0886 & 0.9565 \\
\hline
\end{tabular}

${ }^{1}$ The model is $\mathrm{Y}=\mathrm{a}(\mathrm{x})^{\mathrm{b}}$ where $\mathrm{Y}=$ cumulative radial growth $(\mathrm{mm})$ and $\mathrm{x}=$ age at breast height (years).

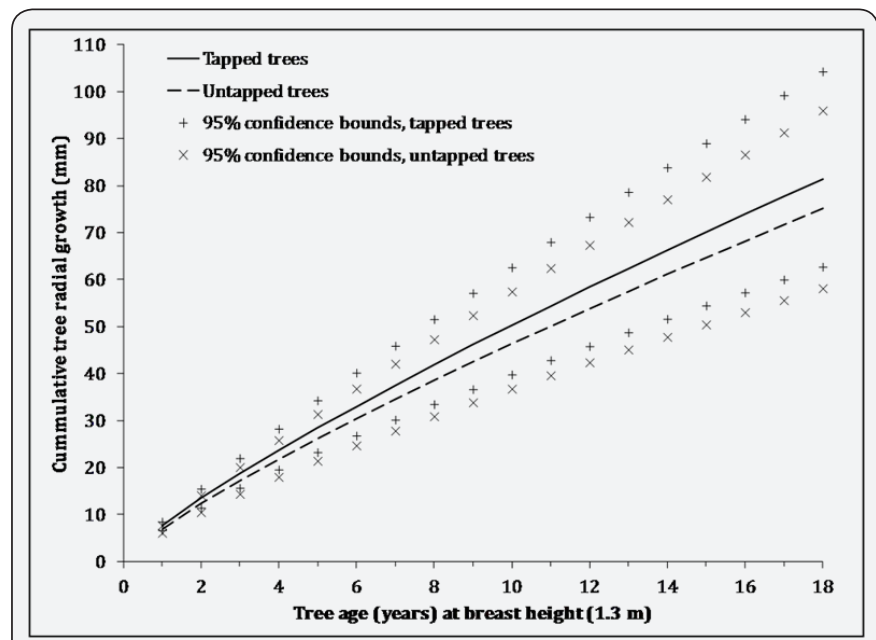

Figure 1: The cumulative radial growth of tapped and untapped trees of Masson pine near Liuzhou, Guangxi in south China. The $95 \%$ confidence bounds of each model are plotted, indicating no significant difference between the models since the confidence bounds overlap.

Wang [16] found that resin tapping of Chinese red pine (Pinus tabulaeformis Carr.) decreased dbh growth by $1.34 \%$, but more importantly resulted in a decrease in stem volume by $18.62 \%$. How much, if any, the tapping of trees in this study influenced stem volume we do not know. Nevertheless, a combined management strategy of resin tapping with timber production may still provide a means by which forest farmers can maximize their income, despite any reductions in stem volume that may occur as a result of resin tapping. Wang [4] found that a combined management strategy of resin tapping with timber production of Masson pine can produce an internal rate of return of $37 \%$, depending on the current markets and costs. This is a $76 \%$ increase of the internal rate of return over a management strategy of timber production alone. The combined strategy of resin collection and timber production reduced the payback period by $45 \%$.

\section{Conclusion}

We could not find any effect of resin tapping on Masson pine trees in this study. However, this may be a result of the sampling design in that we did not sample any other location on the bole of the tree. We would encourage the combined management of resin tapping and timber production in these stands. Resin tapping provides periodic income during the rotation of the stand that otherwise would not occur with timber production alone. Even though there would be limited use of the injured portion of the bole for wood products, it still has utilization value. The portion of the bole above the injured section has full utilization value, even though the stem volume may have been reduced due to tapping.

\section{Acknowledgements}

The author would like to thank Dr. Yuhua Tao and students of Guangxi Ecological Engineering Vocational and Technical College for their assistance in the data collection. This project was funded by the China Research Abroad Program, School of Environment and Natural Resources at The Ohio State University. 


\section{Conflict of Interest}

The authors declare that no economic interest or any other conflict of interest exists with any institution or individuals involved in the collection of data or writing of this paper.

\section{References}

1. Coppen JJ, Hone GA (1995) Gum Naval Stores: Turpentine and Rosin from Pine Resin. Non-Wood Forest Products 2. Natural Resources Institute, FAO, Rome, Italy.

2. Lee HJ, Ravn MM, Coates RM (2001) Synthesis and characterization of abietadiene, levopimaradiene, palustradiene, and neoabietadiene: hydrocarbon precursors of the abietane diterpene resin acids. Tetrahedron 57(2001): 6155-6177.

3. Kelkar VM, Geils BW, Becker DR, Overby ST, Neary DG (2006) How to recover more value from small pine trees: essential oils and resins. Biomass Bioenerg 30: 316-320.

4. Wang Y, Guo F, Zhang M, Yang Z (2011) Analysis and evaluation on economic benefit of pinus massoniana plantation for timber and resin production -taking Guangxi Paiyangshan State Forest Farm as an example. Issues of Forestry Economics 6: 5.

5. Liu Q, Zhou Z, Fan H, Liu Y (2013) Genetic variation and correlation among resin yield, growth, and morphologic traits of Pinus massoniana. Silvae Genetica 62(1-2): 38-44.

6. Rodríguez-Garcíaa A, Martína JA, Lópeza R, Sanzb A, Gil L (2016) Effect of four tapping methods on anatomical traits and resin yield inMaritime pine (Pinus pinaster Ait.). Industrial Crops and Products 86: 143-154

7. Wink M (1988) Plant breeding: importance of plant secondary metabolites for protection against pathogens and herbivores. Theor Appl Genet 75(2): 225-233.
8. Lewinsohn E, Gijzen M, Croteau R (1991) Defense-mechanisms of conifers-differences in constitutive and wound-induced monoterpene biosynthesis among species. Plant Physiol 96(1): 44-49.

9. van der Maaten E, Mehl A, Wilmking M, van der Maaten-Theunissen M (2017) Tapping the tree-ring archive for studying effects of resin extraction on the growth and climate sensitivity of Scots pine. Forest Ecosystems 4: 7.

10. Tomusiak R, Magnuszewski M (2009) Effect of resin tapping on radial increments of Scots pine (Pinus sylvestris L.). In: Kaczka $\mathrm{R}$, Malik I, Owczarek P, Gärtner H, Helle G, et al. (Eds.), Trace-Tree Rings in Archaeology, Climatology and Ecology. Proceedings of the Dendrosymposium 2008, April $27^{\text {th }}-30^{\text {th }} 2008$, Zakopane, Poland, GFZ Potsdam, Scientific Technical Report STR 09/03, Potsdam, pp. 151-157.

11. Chen F, Yuan Y, Yu S, Zhang T (2015) Influence of climate warming and resin collection on the growth of Masson pine (Pinus massoniana) in a subtropical forest, southern China. Trees 29(5): 1423-1430.

12. Yuan T, Yang Z, Tan R, Meng C (2013) Benefit assessment on early tapping of Pinus elliottii. Asian Agricultural Research 5(9): 100-102.

13. Kang B, Liu S, Zhang G, Jianguo J, Wen Y, et al. (2006) Carbon accumulation and distribution in Pinus massoniana and Cunninghamia lanceolata mixed forest ecosystem in Daqingshan, Guangxi, China. Acta Ecologica Sinica 26(5): 1320-1329.

14. Zheng H, Ouyang Z, Xu W, Wang X, Miao H, et al. (2008) Variation of carbon storage by different reforestation types in the hilly red soil region of southern China. For Ecol Manag 255: 1113-1121.

15. SAS Institute Inc (2008) Statistical Analysis System software, version 9.2, Cary, NC, USA.

16. Zhan-qin W, Zhi-ming W, Zhan-wen Y (2007) Preliminary Study on Effect of Resin Tapping on Growth of Pinus tabulaeformis. Shanxi Forestry Science and Technology.

\section{Your next submission with Juniper Publishers will reach you the below assets}

- Quality Editorial service

- Swift Peer Review

- Reprints availability

- E-prints Service

- Manuscript Podcast for convenient understanding

- Global attainment for your research

- Manuscript accessibility in different formats

( Pdf, E-pub, Full Text, Audio)

- Unceasing customer service

Track the below URL for one-step submission https://juniperpublishers.com/online-submission.php 